\title{
Understanding a Period of Policy Change: The Case of Hydraulic Fracturing Disclosure Policy in Colorado
}

\author{
Tanya Heikkila \\ School of Public Affairs, University of Colorado Denver \\ Jonathan J. Pierce \\ School of Public Affairs, University of Colorado Denver \\ Samuel Gallaher \\ School of Public Affairs, University of Colorado Denver \\ Jennifer Kagan \\ School of Public Affairs, University of Colorado Denver \\ Deserai A. Crow \\ School of Journalism and Mass Communication, University of Colorado at Boulder \\ Christopher M. Weible \\ School of Public Affairs, University of Colorado Denver
}

\begin{abstract}
This paper investigates the beliefs and framing strategies of interest groups during a period of policy change and the factors explaining policy change. We develop propositions to explore questions concerning policy change primarily from the advocacy coalition framework as well as from other theorie. The propositions are tested by examining the promulgation of a Colorado regulation requiring the disclosure of chemicals used in hydraulic fracturing. Using coded data of documents published by organizations involved in the rulemaking process, we find divergence between industry and environmental groups on their beliefs concerning hydraulic fracturing, as well as their portraying themselves and each other as heroes, victims, and villains, but some convergence on their more specific beliefs concerning disclosure of chemicals. Interviews point to the importance of policy entrepreneurs, timing, a negotiated agreement, and learning for explaining policy change. The findings provide both theoretical and methodological insights into how and why policy changes.
\end{abstract}

KEY WORDS: energy, environment, governance, pollution

O ne of the enduring topics of study for scholars of public policy is how policies change. Some scholars have focused on explaining instances of policy change over time (Baumgartner \& Jones, 1993; Donnelly \& Hogan, 2012; Sabatier \& Jenkins-Smith, 1993). Others have analyzed how contextual factors, including socioeconomic and institutional factors, influence policy change across space and time (Berry \& Berry, 1990; Blomquist, 2007; Hofferbert, 1974; Walker, 1969). The results are laudable. We now have a better understanding of the temporal frequency of policy change, as well as the contextual and temporal conditions favoring policy change. However, the causal mechanisms of particular instances of change remain underdeveloped or are often not well integrated across the literature (John, 2003).

A common strategy for studying policy change has been the use of large- $n$ cross-sectional or longitudinal research designs. Although gains in descriptive and

Review of Policy Research, Volume 31, Number 2 (2014) 10.1111/ropr.12058

(C) 2014 by The Policy Studies Organization. All rights reserved. 
explanatory insight from such research designs are substantial, lessons can also be learned by studying a single period of policy change. First, such a study can shed light on how policy change processes unfold over time, potentially revealing causal mechanisms that may be difficult to detect in large-n studies. Second, it can allow for the exploration of a range of theoretical explanations of why policy change occurs. By doing so, studying a single process can provide an opportunity to explore theoretical factors that explain an instance of policy change (George \& Bennett, 2005; Gerring, 2007).

The case study analyzed here focuses on a rule adopted in 2011 by the Colorado Oil and Gas Conservation Commission (COGCC), which regulates oil and gas development in the state. The rule requires the disclosure of chemicals used in hydraulic fracturing, a technique that has become widely used in recent years for high-volume drilling of oil and gas in shale formations. How to regulate hydraulic fracturing has become hotly debated in Colorado (Davis, 2012) and across many other states that overlie shale formations (Fisk, 2013; Warner \& Shapiro, 2013). Questions related to environmental and health impacts of hydraulic fracturing have mobilized an intense political opposition, particularly surrounding the potential health and environmental risks associated with the chemicals in hydraulic fracturing fluids. In response to these concerns, Colorado and a number of other states have established policies mandating that oil and gas companies publicly disclose the chemicals used in their hydraulic fracturing fluids.

Colorado's disclosure rule, although similar in many respects to other disclosure policies of the time, stands out as one of the exemplar cases (Murrill \& Vann, 2012) and, therefore, is an important case to study. Additionally, Colorado's disclosure rule is a valuable case because it represents a substantial change to Colorado's oil and gas regulations. Although Colorado's disclosure rule is not an example of major policy change (i.e., a change in the normative goals of oil and gas policy, inclusive of hydraulic fracturing, in Colorado), the potential impact of the change on the policy process and society is significant. The change in policy altered the instrumental operations of the oil and gas industry; led to an intense political debate involving proprietary information and normative right-to-know expectations in democratic societies; changed how the oil and gas industry relates to the public through greater transparency; and, possibly, increased the likelihood that oil and gas development will be safer for the environment and public health in the future.

In studying Colorado's disclosure rule, our focus is on understanding the political relations among competing interest groups involved in the rulemaking process and factors that explain how and why such a change happened in 2011. In our analysis of how the Colorado disclosure policy change unfolded, we ask the following: 1) What were the beliefs and framing strategies of key interest groups at the period of policy change and 2) how did these beliefs and framing strategies change during the period of policy change? To guide our examination of the first set of questions, we draw heavily from the advocacy coalition framework (ACF) (Sabatier \& Jenkins-Smith, 1993) and the narrative policy framework (NPF) (Jones \& McBeth, 2010). In exploring why the change occurred, we ask: What were the key explanatory factors or mechanisms that precipitated the policy change? To guide this question, we again draw heavily from the ACF but also complementary insights 
from other theories. Given the contentiousness, visibility, national implications, and complexity of this issue, hydraulic fracturing is likely to be an important area of research for scholars in coming years. Additionally, given that research on this topic is in its infancy, we argue that an in-depth case analysis can contribute to developing better understanding of hydraulic fracturing politics and policy. Other scholars, for instance, have argued that exploring a case of state-level policy on hydraulic fracturing can inform scholarly debates around subnational environmental policy leadership (Rabe \& Borick, 2013). In studying the Colorado disclosure rule, we therefore consider how our findings can inform both the broader literature on policy change and the emerging literature on the politics and policies regulating hydraulic fracturing.

\section{Beliefs, Framing Strategies, and Policy Change}

\section{Understanding Beliefs and Framing Strategies in a Period of Policy Change}

Studying the beliefs of individual policy actors provides insights into how interest groups align to form allies and opponents to influence policy outcomes and on what issues the groups involved are likely to come to an agreement on policy goals or instruments. To help conceptualize and measure these beliefs, the ACF posits two forms of beliefs relevant for this study: policy core and secondary beliefs. ${ }^{1}$ Policy core beliefs are the basic priorities, goals, and values related to a particular issue; examples include general policy preferences, perceptions of problems spanning the scope of an issue, or perceptions of whose welfare counts. Secondary beliefs are more narrow and specific, often involving empirical descriptions of the world, subissues related to the policy debate, or the beliefs concerning the means or instruments for achieving the goals of a policy. The ACF predicts interest groups coalesce more around the former and less around the latter (e.g., Sabatier, 1988; Sabatier \& Jenkins-Smith, 1993; Weible, Heikkila, deLeon, \& Sabatier, 2011). We draw from the ACF in proposing that in a period of policy change when policies are disputed, opposing interest groups tend to be more divided on policy core beliefs than on secondary beliefs.

In a period of policy change, an important question is whether or how the beliefs of policy actors in competing interest groups change and ultimately converge on policy issues or positions. A long-standing literature assumes that belief systems are hierarchical, where some beliefs are more stable than others (Converse, 1964; George, 1969; Hurwitz \& Peffley, 1987). The ACF adopts this hierarchical assumption concerning belief systems and posits that policy core beliefs (beliefs concerning goals) are more stable than secondary beliefs (beliefs concerning means) (Sabatier, 1988; Sabatier \& Jenkins-Smith, 1993). Therefore, in examining a period of policy change, we propose that policy core beliefs will be more stable than secondary beliefs over time.

In addition to studying how policy actors coalesce around beliefs within interest groups and whether those beliefs change, it is beneficial to explore the strategies of interest groups in trying to understand a period of policy change. Generally, strategies differ from policy beliefs in that they refer to the actions taken by policy actors or interest groups to achieve policy goals supporting their beliefs (Rokeach, 
1973). In other words, strategies are the means by which interest groups seek to achieve their objectives, policy beliefs. Therefore, the types of strategies that interest groups employ can help illuminate how policy actors achieve their political objectives in a policy process. To win policy disputes, interest groups will strategically portray themselves and their opponents as playing different characters or roles (Shanahan, Jones, \& McBeth, 2011; Shanahan, Jones, McBeth, \& Lane, 2013). Based on the NPF, we investigate the extent to which interest groups characterize themselves and others as villains (those causing harm), victims (those suffering from harm), or heroes (those attempting to fix or prevent harm). We propose that interest groups are more likely to portray their opponents as villains than themselves, and more likely to portray themselves as heroes or victims than their opponents.

Such strategies used by interest groups of portraying themselves and their opponents as victims, villains, or heroes may not be stable (McBeth, Shanahan, Hathaway, Tigert, \& Sampson, 2010). Studying changes in strategies can provide insights on interest group learning in a policy process, particularly whether interest groups react and respond to strategies of their opponents or adjust their strategies to other changes in the political context (for example, new information). As time passes in any policy dispute, research has found that interest groups adjust their framing strategies to achieve their political objectives (Berger, 1997; Cormier \& Tindall, 2005; Levin, 2005; Shanahan et al., 2011). Therefore, we propose that the framing strategies used by interest groups in portraying themselves and others as villains, victims, or heroes will change over time.

\section{Understanding the Factors that Precipitate Policy Change}

Understanding the beliefs and strategies of policy actors can inform how policy change processes unfold, particularly how actors and interest groups engage and position themselves in the process. To answer our second research question, we draw primarily from the ACF and other theories to derive six propositions that lay out factors that are likely to precipitate policy change. ${ }^{2}$ Three of these propositions represent a fairly comprehensive testing of the different pathways for policy change under the ACF, including major events, learning, and negotiated agreements affecting policy change. ${ }^{3}$ The other three propositions are compatible with the ACF but draw from other theoretical traditions.

The rationale for utilizing multiple theoretical explanations for understanding a period of policy change is not to merge theories into a single comprehensive "theory" of policy change; rather, the intent is to offer a more comprehensive and valid explanation of policy change in a case study. Many studies of comparative politics aim to test and compare insights from multiple theories; this study is no different. The benefits of this multitheoretical effort include the opportunity to explore a wider range of explanations for policy change without the constraints imposed by any single theory. Such practical benefits are nontrivial, particularly in the context of a relatively new policy debate, such as hydraulic fracturing, where the pathways to policy change have not been explored extensively. ${ }^{4}$

Timing-Kingdon's (1984) multiple streams theory focuses on an axiom of politics that timing matters in setting policy agenda and shaping policy alternatives. The 
right timing comes from the intersection of a number of factors that Kingdon organized into three independent "streams": recognized problems, existing solutions, and political will. Therefore, we propose that the merging of problems, solutions, and politics will precipitate policy change. ${ }^{5}$

Major Events-Major events are mentioned as a mechanism for policy change in the ACF as well as almost every policy theory. These events include regime shifts, demographic or economic changes, crises, revolutions, and technological breakthroughs (Birkland, 1997; Kingdon, 1984; Ostrom, 2005; Sabatier \& Jenkins-Smith, 1993). The rationale is partly rooted in system theory and the tendency for systems to settle in a stable equilibrium that requires one or more stimulants to change (Easton, 1954). Thus, events are theorized as one of these stimulants that may overcome the institutional friction in a stable state, often by shifting resources or perceptions (Jones \& Baumgartner, 2005; Weible et al., 2011). However, the exact relationship between major events and policy change is less clear. Connecting an event to policy change will likely depend upon the intrinsic nature of the event combined with how the event is interpreted by the policy actors (Nohrstedt \& Weible, 2010). Additionally, major events may compound each other or occur in sequence. Based on the literature, we propose that one or more major events will precipitate policy change.

Diffusion-A long-standing research tradition in political science and public policy for understanding cognitive, behavioral, or policy change is diffusion or transfer processes (Berry \& Berry, 1990; Rogers, 1962; Shipan \& Volden, 2008; Walker, 1969). Diffusion processes work from the assumption that units, from people to governments, are interdependent; the objective is to understand the extent that ideas, policies, or lessons transfer from one unit to another. For example, Rose (1991) describes this as lesson drawing, and similarly, Richardson (2000) describes how policy ideas transfer akin to viruses (see also Cairney, 2012). What the diffusion models of policy change suggest is that policy change may be more likely when policy actors learn about or observe policy ideas adopted or implemented by other governments or decision-making units. Therefore, we propose that adoption of similar policies by other government jurisdictions will precipitate policy change.

Negotiated Agreements-Another common way to stimulate policy change under the ACF is through formal processes of negotiation among opposing interest groups (Sabatier \& Weible, 2007). Building from the alternative dispute literature (Susskind, McKearnen, \& Thomas-Lamar, 1999), negotiated agreements are thought to be a viable path for policy change when political opponents perceive no alternative venues to achieve their policy goals and also realize that the status quo is unacceptable. Conditions for successful agreements include consensus-based decision rules, experienced leaders, adequate funding, face-to-face communication and trust, commitment to the process by all parties, adequate representation of stakeholder interests, and political recognition of the process (Emerson, Nabatchi, \& Balogh, 2012; Leach \& Sabatier, 2005; O'Leary \& Bingham, 2003; Sabatier \& Weible, 2007). Thus, we propose that negotiations between opponents will precipitate policy change. 
Policy Entrepreneurs-Policy entrepreneurs, a common actor category described in theories of policy change, are the champions of an idea (e.g., Kingdon, 1995; Mintrom \& Norman, 2009). They are individuals with expertise, resources, and a leadership position within an organization and who are willing to bear the transaction cost in advocating for an idea persistently over time (Kingdon, 1995, pp. 180-181). Sometimes entrepreneurs have skills in negotiation and political persuasion, thus, filling the position of a policy broker. Policy entrepreneurs also are likely to be skilled at strategically framing policy problems or solutions to garner public support, as well as taking advantage of windows of opportunity for change (Kingdon, 1995). Thus, policy entrepreneurs have long been predicted to play an important role in policy change, including under the theoretical logic of the ACF (Mintrom \& Vergari, 1996). In an instance of policy change, we propose that a policy entrepreneur will play a role in precipitating policy change.

Learning - Learning is another commonly identified path to policy change, particularly within the ACF (Gerlak \& Heikkila, 2011; Heclo, 1974; Leach, Weible, Vince, Siddiki, \& Calanni, 2013; May, 1992; Sabatier, 1988; Weiss, 1977). Learning in a policy process involves both processes and products (Heikkila \& Gerlak, 2013). The process of learning might entail communication or exposure to new information, perhaps from an event or negotiation. Such processes are necessary for learning products to emerge, which include cognitive changes among policy actors, or as defined by Sabatier (1987): "relatively enduring alterations of thought or behavioral intentions that result from experience and that are concerned with the attainment or revisions of the precepts of one's belief system" (p. 672). It is when policy actors engage in learning and alter their beliefs that they can come together on new understandings of policy problems or solutions, which can facilitate policy change. We therefore propose that learning by policy actors will precipitate policy change.

\section{Context and Background on the Disclosure Issue and the Colorado Case}

Hydraulic fracturing is the technique of injecting water, sand, and chemical additives thousands of feet underground into shale rock or other porous formations. This mixture of components makes up the hydraulic fracturing fluid that fractures the shale rock releasing either oil or natural gas that comes to the surface via the well. The technique was first introduced in the 1940s and has become widely adopted in the past decade by the oil and gas industry. The United States has a vast supply of natural gas trapped in shale rock that it may now extract because of developments in hydraulic fracturing and horizontal drilling technology. In 2000, natural gas from shale provided only about 1 percent of the total natural gas production in the United States, but by 2010, shale gas increased to 23 percent of natural gas production, and by 2035 , it is expected to rise to 49 percent of national natural gas production and generate about 25 percent of the electricity used in the United States (U.S. EIA, 2012).

Along with the rapid development of shale gas and shale oil has come intense political debate concerning how it should be regulated and by whom in various states, including Colorado (Davis, 2012), Pennsylvania (Rabe \& Borick, 2013), Texas (Davis, 2012), Arkansas, Ohio, Oklahoma, and Louisiana (Warner \& Shapiro, 2013). 
This intense political debate is, in part, being driven by conflicts between those who support the practice, often extractive industries and the state governments that desire the tax dollars, and those who oppose the practice, including environmental and local citizen organizations as well as local governments (Davis, 2012; Entrekin, Evans-White, Johnson, \& Hagenbuch, 2011; Fisk, 2013; Jackson, Rainey Pearson, Osborn, Warner, \& Vengosh, 2011; Lustgarten, 2009; Maykuth, 2011). Although the news media in recent years has paid significant attention to these debates, scholarly research on the nature of these debates, who is involved, and how stakeholders are organizing and influencing policy is just beginning to emerge in the literature.

One of the most visible debates is related to the potential risks to public health and the environment associated with the chemicals used in hydraulic fracturing fluids (Fisk, 2013; Mooney, 2011). Concerns regarding the alleged risks associated with hydraulic fracturing began to be addressed at the state level in 2010 when Wyoming and Arkansas decided to mandate the disclosure of chemicals used in hydraulic fracturing. Following the Texas 2011 disclosure law and rulemaking, Colorado began the process to promulgate new public disclosure rules in the summer of 2011. The process followed changes that Colorado made in 2007 and 2008 to its rules and regulations governing oil and gas to include the protection of public health, safety, and welfare, and responsible development of Colorado's natural resources. The 2011 rulemaking process was instigated by Colorado Governor John Hickenlooper, who in August of that year addressed the Colorado Oil and Gas Association (COGA) arguing that companies should disclose the chemical components in hydraulic fracturing fluid. Governor Hickenlooper stated that he did not believe that hydraulic fracturing posed a serious risk to groundwater, "[b]ut the industry needs to be transparent. It needs to demonstrate, beyond a doubt, that this doesn't happen" (Jaffe, 2011a). Representatives from the oil and gas industry and the COGCC concurred with Governor Hickenlooper that transparency by the oil and gas industry concerning hydraulic fracturing was needed to build public trust (Jaffe, 2011b; Williams, 2011).

In August 2011, the COGCC began informal meetings with representatives of the oil and gas industry and environmental groups concerning a disclosure rule. The discussions developed into formal meetings on October 25 th when the COGCC released the first notice of the formal rulemaking process. On December 5 , the COGCC held a hearing to consider the proposed rule changes. This hearing included public comments and presentations by interest groups who were formal parties to the rulemaking process. On December 13, the COGCC deliberated and eventually adopted an agreement regarding the disclosure of the chemicals used in hydraulic fracturing. According to the new rule (2 CCR 404-1 Rule 205A), companies are required to disclose the total volume of water used, chemicals in the additives, and chemical concentrations on the public website FracFocus.org. The disclosure rule permits companies to claim that chemicals in the additives, concentrations of chemicals, or both are trade secrets, though the chemical family (a classification of chemicals with similar properties) must be posted on FracFocus.org. Public health professionals and regulators can request that companies disclose trade secret ingredients when the information is necessary to treat exposed individuals or respond to spills, but the ingredients must remain confidential from the public. 
The public disclosure rule in Colorado was supported and championed as a victory by both industry and environmental groups (Jaffe, 2011c; Staff, 2011). Colorado's disclosure rule on hydraulic fracturing fluids has been recognized as a model for the nation and future regulation of hydraulic fracturing because it balances the public desire to know what and how much of certain chemicals are in the fluid with the protection of trade secrets for the industry (Murrill \& Vann, 2012; Interview \#7). The rule has a number of features designed to accomplish this objective. First, Colorado's rule recognizes the importance of chemical abstract service numbers and not only the chemical name. This allows for greater ease of research in the scientific literature concerning specific chemicals. Second, the rule includes the maximum concentration of each ingredient within the fluid, providing not only qualitative information but quantitative information concerning the chemicals used. Third, to protect trade secrets and prevent reverse engineering of the fluids, the rule does not require parties to connect the ingredients or chemical to the exact additive of which they are a part and combine to form the fluid. The Colorado rule also gives the commission director or designee the ability to disclose trade secret information to other COGCC staff, commissioners, the Public Health Director, or the emergency manager as necessary in the case of spills or releases. In our analysis that follows, we aim to understand some of the key factors explaining how and why this rule was created.

\section{Methods}

To understand the policy process that led to the adoption of the December 2011 disclosure rule in Colorado, we relied on two sources of data: direct communication documents by policy actor organizations and interviews with policy actors. First, we coded documents written and distributed by policy actors engaged in the disclosure rulemaking process in Colorado. To capture the documents produced by the actors in the sample, we searched all websites from a sample of policy actors gathered through multiple sources, including the COGCC website of recognized stakeholders; attendees of public hearings; attendees and presenters at academic, government, environmental, and industry-sponsored conferences; public protests; and other events related to the use of hydraulic fracturing for the development of oil and natural gas in Colorado. From this sample of policy actors in Colorado, we identified approximately 200 organizational websites. A search for pdf or html files on these websites was conducted using Google Chrome, Yahoo! Search, and Download Master. Documents were included in the sample if they 1) focused on hydraulic fracturing in Colorado or hydraulic fracturing generally; 2) were dated between January 1, 2011 and July 1, 2012 (to capture both the rulemaking period and the months preceding and following the process); 3) were written, published, or posted by an organization involved in the disclosure rulemaking process in Colorado; and 4) included any of the following terms: natural gas and shale, hydraulic fracturing, hydrafracking, hydra fracking, hydrofracking, hydro fracking, fracking, fracing, play and shale, or shale gas. The document sample was further limited to those documents, including some form of the word disclosure (disclosure, disclose, disclosed, or disclosing), a focus on the hydraulic fracturing fluids, or trade secrets. 
Based upon these search criteria, a total of 134 documents were identified from 42 different organizations. These organizations represented interest groups from environmental conservation groups; the oil and gas industry; as well as local, state, and federal government documents. For the purposes of this paper, the data analyses from our coded documents were limited to the two competing interest groups that produced the lion's share of all documents in the sample-industry $(\mathrm{n}=51)$ and environmental $(\mathrm{n}=53)$ organizations-and did not include the documents gathered from local, state, and federal governments. ${ }^{6}$

Each of the documents was coded by one of three coders using a codebook iteratively developed and based on the NPF (Jones \& McBeth, 2010). The codebook includes basic identification information concerning each document, such as the document type, publisher, and word count. Substantive codes include indicators of the types of policy core beliefs related to positions on hydraulic fracturing presented in the document (e.g., a pro versus con stance); the types of secondary policy beliefs or policy preferences exhibited in the document (e.g., support for disclosure or not); as well as whether the document employs character framing, namely the identification of actors or organizations as heroes, victims, and villains in relation to the issue of hydraulic fracturing. ${ }^{7}$ Based upon the NPF, we use the following definitions of heroes, villains, and victims. A hero is an actor who plans to or fixes, solves, assists, or seeks to resolve past, current, or future problem(s). Heroes need to possess intention and/or agency. A villain is an actor who intentionally creates, causes, contributes to, instigates, exacerbates, or plans to contribute to the problem. The victim is an actor who suffers, is targeted, or is affected by the problem and/or villain. Character framing serves as an indicator of policy actor strategies. An intercoder reliability test_Cohen's Kappa (Cohen, 1960)—was conducted on policy core and policy preference $\operatorname{codes}^{8}$ by a second coder on a random sample of 30 documents or 22.4 percent of the population. ${ }^{9}$ The Cohen's Kappa statistic for all of these codes was greater than $0.40 .{ }^{10}$

The coded documents were used as the primary data source for exploring our propositions related to the beliefs and framing strategies used by the two interest groups involved in the disclosure issue. To analyze the documents, we calculated mean scores of the number of codes identified across the two interest groups' documents for the specific policy core and secondary beliefs, and by calculating the percentage of documents that identify policy actors from their own interest group or policy actors from other interest groups as victims, villains, or heroes. To analyze whether these beliefs or strategies of the groups changed over time, we divided the documents into three distinct time periods: 1) immediately prior to the policy process from January 1, 2011 to October 25, $2011(\mathrm{n}=32,35$ percent); 2) during the policy process from October 26, 2011 to December 13, 2011 ( $\mathrm{n}=46,40$ percent); and immediately after the policy process from December 14, 2011 to July 1,2012 ( $\mathrm{n}=26,25$ percent).

In addition to the coded documents, we conducted interviews with policy actors from 14 different organizations who were involved with, or active in, the disclosure rulemaking process. We used a guided, open-ended interview instrument that asked interviewees to describe the issues or problems addressed in the disclosure rulemaking process, how those issues got onto the policy agenda, who was involved in the rulemaking, whether and how consensus was reached within or between 
different interest groups, and whether the rule effectively resolved the problems it was intended to address. Qualitative analysis of these interviews is used to explore our propositions regarding the factors that precipitate policy change. Our interview data regarding actors' positions on the problems and issues also provide evidence of beliefs that support the document coding.

\section{Findings: Beliefs and Framing Strategies of Key Interest Groups}

\section{Alignment of Interest Groups around Beliefs on Hydraulic Fracturing}

Our first proposition is that opposing interest groups tend to be more divided on policy core beliefs than on secondary beliefs. The results from the analysis of the coded data on the policy core beliefs (measured as general support-pro or con-for hydraulic fracturing) of the two key interest groups are shown in the top portion of Table 1 . The industry interest group $(n=51)$ has a mean of 0.86 in favor of hydraulic fracturing. In contrast, the environmental interest group's $(n=53)$ mean score is -1 , indicating strong opposition. These data indicate that the industry and environmental interest groups are clearly divided on their policy core beliefs.

The bottom portion of Table 1 shows the mean scores for the two groups regarding the secondary belief of whether to regulate hydraulic fracturing using disclosure. For both interest groups, the mean is greater than 0.66 , indicating that a majority of documents from both interest groups supported disclosure. Overall, Table 1 confirms the first proposition that opposing interest groups tend to be more divided on policy core beliefs than on secondary beliefs.

\section{Investigating Changes in Policy Core and Secondary Beliefs}

The second proposition is that policy core beliefs will be more stable than secondary beliefs over time. Table 2 lists the mean scores for policy core and secondary beliefs by interest groups over the three key time periods of the disclosure rulemaking process (pre, during, and post). The findings show that environmental groups' policy core and secondary beliefs are more stable than those of industry. The mean scores for both policy core and secondary beliefs are approximately the same for environmental groups over time. At least for the environmental groups, we see no support for the argument that secondary beliefs are less stable than policy core beliefs.

Table 1. Comparing Policy Core and Secondary Beliefs of Industry and Environmental Groups on Hydraulic Fracturing (Means Shown)*

\begin{tabular}{|c|c|c|c|}
\hline & & $\begin{array}{l}\text { Industry }(\mathrm{n}=51 \\
\text { Documents) }\end{array}$ & $\begin{array}{c}\text { Environmental Groups } \\
(\mathrm{n}=53 \text { Documents })\end{array}$ \\
\hline $\begin{array}{l}\text { Policy Core Beliefs } \\
\begin{array}{l}(1=\text { pro, }-1=\text { anti } \\
0=\text { neutral })\end{array}\end{array}$ & $\begin{array}{l}\text { Natural gas development that } \\
\text { utilizes hydraulic fracturing }\end{array}$ & 0.86 & -1.00 \\
\hline $\begin{array}{l}\text { Secondary beliefs } \\
(1=\text { pro, } 0=\text { anti or neutral })\end{array}$ & $\begin{array}{l}\text { Disclosure of chemicals in } \\
\text { hydraulic fracturing fluids }\end{array}$ & 0.67 & 0.91 \\
\hline
\end{tabular}

*Data sources: 142 documents, published online between January 2011 and July 2012 by 42 organizations involved in hydraulic fracturing policy debates in Colorado. 
Table 2. Comparing Changes in Policy Core and Secondary Beliefs of Interest Groups on Hydraulic Fracturing (Means Shown)*

\begin{tabular}{|c|c|c|c|c|c|c|}
\hline & \multicolumn{3}{|c|}{ Industry } & \multicolumn{3}{|c|}{ Environmental Groups } \\
\hline & Before & During & After & Before & During & After \\
\hline $\begin{array}{l}\text { Number of documents coded } \\
\text { Policy core belief measures }\end{array}$ & 19 & 22 & 9 & 17 & 20 & 17 \\
\hline $\begin{array}{l}\text { Pronatural gas development with hydraulic fracturing } \\
\quad(1=\text { pro, }-1=\text { anti, } 0=\text { neutral })\end{array}$ & 0.69 & 0.94 & 1.00 & -1.00 & -1.00 & -1.00 \\
\hline Secondary belief measures & 047 & 085 & 080 & 088 & 100 & 089 \\
\hline
\end{tabular}

*Data sources: 142 documents, published online between January 2011 and July 2012 by 42 organizations involved in hydraulic fracturing policy debates in Colorado.

Table 3. Comparing Identification of Heroes, Villains, and Victims by Interest Group*

\begin{tabular}{lcc}
\hline & Industry & $\begin{array}{c}\text { Environmental } \\
\text { Groups }\end{array}$ \\
\hline $\begin{array}{l}\text { Documents coded with self as heroes minus percent of documents coded with } \\
\text { other as heroes (\%) }\end{array}$ & 55 & 60 \\
$\begin{array}{l}\text { Documents coded with self as victims minus percent of documents coded with } \\
\text { other as victims (\%) }\end{array}$ & 24 & 0 \\
$\begin{array}{l}\text { Documents coded with other as villains minus percent of documents coded with } \\
\text { self as villains (\%) }\end{array}$ & 2 & 87 \\
\hline
\end{tabular}

*Data sources: 142 documents, published online between January 2011 and July 2012 by 42 organizations involved in hydraulic fracturing policy debates in Colorado.

Note. Percentages indicate the difference between the percent of documents coded by one policy actor category and the other policy actor category. For example, industry cites environmental groups as victims in $0 \%$ of the coded documents and themselves as victims in $24 \%$, which creates a difference of $24 \%$.

The mean changes in beliefs for industry are more complicated. Secondary beliefs on prodisclosure changed substantially from 0.47 before the disclosure process to 0.85 and 0.80 during and after the disclosure rulemaking process. A similar change can be found with policy core beliefs where industry's beliefs concerning pronatural gas development increased from 0.69 to nearly 1.0 during and after the rulemaking process. Overall, we do not find clear evidence to support the second proposition that policy core beliefs will be more stable than secondary beliefs over time. Environmental groups remained stable for the entire time period, but industry showed changes in both policy core and secondary beliefs.

\section{Investigating Strategic Framing by Industry and Environmental Interest Groups}

To investigate the strategies of industry and environmental groups, we examine the percentage of documents produced by actors within these groups that strategically frame actors within their own interest group versus the percent that frame actors in the other interest group as heroes, villains, and victims. In any given document, industry and environmental groups may portray multiple actors, including themselves, as victims, heroes, and villains. Thus, Table 3 accounts for the relative extent to which the actors in one interest group category perceive their own group as heroes or victims compared with how the actors in the group perceive the other interest group category. The difference is calculated by taking the average number of coded documents declaring self (industry by industry, environmental groups by environ- 
Table 4. Comparing Changes in Heroes, Villains, and Victims of Industry and Environmental Groups*

\begin{tabular}{|c|c|c|c|c|c|c|}
\hline & \multicolumn{3}{|c|}{ Industry } & \multicolumn{3}{|c|}{ Environmental Groups } \\
\hline & Before & During & After & Before & During & After \\
\hline Number of documents coded & 19 & 22 & 9 & 17 & 20 & 17 \\
\hline $\begin{array}{l}\text { Documents coded with self as heroes minus percent of } \\
\text { documents coded with other as heroes }(\%)\end{array}$ & 58 & 40 & 80 & 41 & 68 & 71 \\
\hline $\begin{array}{l}\text { Documents coded with self as victims minus percent of } \\
\text { documents coded with other as victims }(\%)\end{array}$ & 16 & 41 & 0 & 0 & 0 & 0 \\
\hline $\begin{array}{l}\text { Documents coded with other as villains minus percent of } \\
\text { documents coded with self as villains }(\%)\end{array}$ & -6 & 9 & 0 & 82 & 89 & 88 \\
\hline
\end{tabular}

*Data sources: 142 documents, published online between January 2011 and July 2012 by 42 organizations involved in hydraulic fracturing policy debates in Colorado.

mental groups) as hero minus the average number of coded documents declaring the other (industry by environmental group, environmental group by industry) as hero. For example, industry organizations cite themselves as heroes in 61 percent of the documents coded, but they also identify environmental organizations as heroes in 6 percent of the documents. The difference of 55 percent is reported in Table 3 .

Members of both industry and environmental groups report themselves, compared with the other group, as heroes in about 55 or 60 percent of the documents coded. There is relatively no distinction in how interest group members portray themselves and the other group as heroes. In contrast, there is a stark difference in how they portray each other as villains. Environmental organizations characterize industry as villains in 87 percent of the documents and never characterize themselves as villains. Industry groups portray themselves as villains (4 percent of documents) about at the same frequency as they portray environmental groups as villains (6 percent of documents), for a difference of 2 percent. Few documents identified either interest group as victims. Environmental groups portray themselves and industry as victims in about 2 percent of documents, for a difference of 0 percent. Industry organizations are more likely to identify themselves as victims at a difference of 24 percent. Overall, the results are mixed with respect to the third proposition that interest groups are more likely to portray their opponents as villains than themselves, and more likely to portray themselves as heroes or victims than their opponents. While the portrayal of heroes is consistent with our proposition, the results for villains are inconclusive.

\section{Investigating Changes in Strategic Framing of Heroes, Villains, and Victims over Time}

Table 4 provides the mean differences between self-characterization and characterization of others as heroes, victims, and villains over the three time periods in our study. We find mixed support for the fourth proposition, which is that tactics used by policy actors of identifying themselves and others as villains, victims, or heroes will change over time. The portrayal by the interest groups of themselves as heroes increased over time with the highest percentage of these portrayals coming out after the rule was made. Industry's self-portrayal as victims during the rulemaking process was found in 41 percent of documents, but industry organizations did not portray themselves as victims in any documents after the rule was established. In contrast, 
environmental groups did not portray themselves as victims in any documents. The portrayal of others as villains was relatively stable for both interest groups over time. Overall, we find mixed support for the fourth proposition that the strategy of portraying themselves as villains, victims, or heroes will change over time.

\section{Findings: Factors that Precipitated Policy Change}

Understanding the beliefs and strategies of key interest groups provides insights on how policy actors engaged in the disclosure rulemaking process and how their engagement changed over time, but it does not explain why the new policy came about. To better understand why the new disclosure rule was established, we use data from our 14 interviews of policy actors and explore the different theoretical propositions that explain the factors that are likely to precipitate policy change.

\section{Timing}

Interviewees believe that the timing was ripe for policy change in the summer and fall of 2011. Throughout 2009 and 2010 in Colorado, hydraulic fracturing was increasingly being recognized as a possible threat to the environment and public health, as indicated not by a focusing event (see below under major events) or negative feedback from existing government programs, but rather by formal and informal complaints by citizens and environmental groups to local and state government (Interview \#3, 5). Politically, by the spring of 2011, the COGCC and the oil and gas industry were worried that hydraulic fracturing had become a public relations issue that needed prompt action (Interview \#1). "There was a strong desire by the COGCC and stakeholders to find a regulatory solution before the legislative session [January 2012] in order to prevent politicization of the issue" (Interview \# 1). Environmental groups also wanted the issue to be settled in the COGCC rather than the state legislature (Interview \#3). The state legislature would have become involved if the policy debate was not settled by January 2012 when the new legislative session would begin. The rationale was that, if the issue entered the realm of the state legislature, then the interest groups would lose control over regulation and the result would be a politicized resolution that may hurt public interest (Interview \# 1, 3). At the same time, the idea of disclosure was circulating as a solution among policy actors in Colorado to address some of the public relation issues associated with the oil and gas industry and to assuage some of the concerns of environmental groups. By the spring of 2011, environmental organizations (Interview \#7), the oil and gas industry (Interview \#6), and the newly elected Governor John Hickenlooper (Interview \# 1) all perceived disclosure as a feasible policy response. These findings provide evidence that the coupling of awareness of the problem, political will, and a feasible solution for a disclosure rule were present in the fall of 2011 in support of the proposition that the merging of problems, solutions, and politics will precipitate policy change.

\section{Major Events}

Major events were not regularly identified in our interviews as mechanisms precipitating the disclosure rulemaking process. "There was no 'smoking gun' or single 
event that triggered the attention and need for a policy change to this issue," but rather there were several "scary events" (Interview \#5). One issue raised by multiple interviewees as a possible key event was the discovery and extraction of oil and natural gas resources in the Niobrara play beginning in 2009 (Interview \#8, 10). This discovery shifted oil and gas industry activities away from the rural and sparsely populated Western Slope of Colorado to the more densely populated and urban settings of the Front Range. The increased exposure of local communities to oil and gas development led to greater pressure by citizens on local and state governments for more regulation of hydraulic fracturing (Interview \#3, 13). In addition to this shift in oil and gas activity, some interviewees recognized that the 2010 documentary film Gasland played an important role in highlighting many of the threats posed by hydraulic fracturing to people and the environment. The film brought public and media attention to the issues and contributed to general public distrust of the hydraulic fracturing process (Interview \#2, 3, 5). Our findings do not offer strong support for the proposition that one or more major events will precipitate policy change; however, the accumulation of more minor events may have played a role in this case.

\section{Diffusion}

During 2011, when Colorado was considering the disclosure rule, other states, including Arkansas, Wyoming, Pennsylvania, Michigan, Texas, and Montana, were implementing and/or adopting their own disclosure rules or laws. Interviewees indicated that experiences from these other states did play a role in Colorado. National industry organizations, such as Halliburton, and national environmental groups, such as the environmental defense fund (EDF), debated the disclosure issue in Arkansas in 2010 and in Texas in 2011, and as a result, "persuasion was relatively easy as hard work had been done in Arkansas and Texas prior to Colorado" (Interview \#7). Moreover, the EDF was pushing to emulate the rulemaking process that was occurring in Texas in Colorado (Interview \#7). However, the specific rule designs of these other states were not copied in Colorado (Interview \# 1, 5, 7). This was because "different models of disclosure laws were available by various states . . [but] there is no one size fits all approach" (Interview \#1) because of variation in shale plays, geography, and community characteristics. Therefore, while we find support for the proposition that adoption of similar policies by other government jurisdictions will precipitate policy change, we note that states' rules or laws were not directly transferred into the design of the rule. Policy actors involved in the disclosure rulemaking process in Colorado did, however, draw lessons from their experiences in other states, which influenced the policy outcome in Colorado.

\section{Negotiated Agreements}

The COGCC acted as a mediating venue, holding negotiations directly between the interest groups (Interview \#1, 3, 10, 11). Multiple industry and environmental organizations were identified in the interviews as being involved in the rulemaking process. Industry interest group participants were Halliburton, Shell, Encana, Anadarko, Williams, Noble, and the COGA, and environmental group participants were the EDF, Western Colorado Congress, Colorado Conservation Voters, Colorado 
Environmental Coalition, Earthworks, and Earthjustice. Additionally, negotiations were held with the COGCC and a subset of groups from industry and the environmental organizations. According to our interviews, the COGA and Halliburton represented industry in the negotiations (Interview \#5, 7, 10), and other industry members collaborated with these organizations and were supportive of their positions during the negotiations (Interview \#6). The EDF represented the environmental community in the negotiations (Interview \#6, 10). The Colorado Conservation Voters and Colorado Environmental Coalition were mentioned as important environmental groups but played an auxiliary role in the direct negotiations (Interviews $\# 5,6,10)$. According to interviews, the environmental groups in Colorado had more difficulties cooperating and working together on the disclosure issue than industry groups (Interviews \#5, 8). Although some noted that the negotiations resulted in discontent among environmental interests, others viewed the resulting outcome as a "win-win" because common ground was found on both sides (Interview \# 1, 3). A number of interviewees also noted that it was possible to find common ground because negotiations occurred among a small number of actors, which made finding consensus easier (Interview \#5, 10, 11). Therefore, our interview findings support the proposition that negotiations between opponents will precipitate policy change.

\section{Policy Entrepreneurs}

Governor Hickenlooper was identified by a number of interviewees as the policy entrepreneur who ensured that this rule was adopted (Interview \#3, 5, 6, 10). He achieved this goal by providing "a good and consistent message that this rule would benefit Colorado" (Interview \#3), and he "brought industry, regulators, and environmental groups to agreement on the rule" (Interview \#6). Once Halliburton and the EDF entered into negotiations, the governor worked personally with them to ensure agreement (Interview \#10). Interviewees speculated on several reasons for Governor Hickenlooper to be so active in relation to this rule. One rationale was that the governor was trying to get this policy accepted by the COGCC because he felt it was a more appropriate venue than the state legislature to address the issue (Interview \#3). Others suggested that Governor Hickenlooper wanted Colorado to be a national leader and the model for energy regulation in the country (Interview \# 1, 3). Some representatives of the environmental groups, who believe that the disclosure rule favored industry, argued that Governor Hickenlooper championed this rule because he supports hydraulic fracturing and oil and gas development in Colorado (Interview \#5). Although there was some disagreement concerning his motives, a number of interviewees saw Governor Hickenlooper as responsible for promoting disclosure as an answer to the problem of public perception of the industry and hydraulic fracturing (Interview \#3, 5, 6, 11). The interviews support the proposition that a policy entrepreneur will play a role in precipitating policy change.

\section{Learning}

A number of interviewees reported that learning by members of the oil and gas industry was important in influencing their willingness to come to agreement on a disclosure policy. In 2009 and 2010, the oil and gas industry faced public relations 
difficulties related to hydraulic fracturing (Interview \#6). Many members of the industry felt that the public was misinformed concerning the dangers posed by hydraulic fracturing (Interview \#3). However, according to interviewees, the industry learned that arguments focused on the low risk of groundwater contamination or movement of hydraulic fracturing fluids into the water table-an argument summed up as "you do not need to worry"-did not assuage public concerns (Interview \# 1, 6). Also, a stringent position related to trade secrets did not help matters when it came to public perceptions of the industry. By early 2011, industry members came to agree that some transparency concerning the chemicals involved in hydraulic fracturing was needed (Interview \#3, 6). From the perspective of the oil and gas industry and its representative COGA, the industry learned that, in order to gain public support and change the perception of this process, it needed to support disclosure (Interview \#5, 7). Although interviewees did not offer evidence that points to learning among actors from the environmental interest group prior to the disclosure rulemaking, learning within one of the key interest groups does offer support for the proposition that learning by policy actors will precipitate policy change.

\section{Discussion}

Understanding how and why policies change is an enduring question in the policy process literature. This paper provides an in-depth analysis and description of a policy change in the regulation of oil and gas development in Colorado. Using both content analysis and in-depth interviews, we explored how policy actors position themselves during a policy change-in terms of their beliefs and strategies-and examined the key factors that precipitated the policy change.

From our document analysis, we found that industry and environmental organizations disagreed about their support for oil and gas development that uses hydraulic fracturing, which is not surprising. They disagreed about the impact of hydraulic fracturing on public health and the environment; however, these groups did not hold opposing secondary beliefs. They both agreed that a disclosure rule should be established to regulate hydraulic fracturing. We also found that industry's policy core and secondary beliefs were relatively malleable during the period of policy change. This supported the proposition from the ACF that opposing interest groups tend to be more divided on policy core beliefs than on secondary beliefs. For scholars interested in understanding the nature of debates around hydraulic fracturing and how these debates are being resolved, this finding points to the importance of analytically partitioning hydraulic fracturing debates around core and secondary beliefs. We did not find, however, evidence supporting the proposition that policy core beliefs are more stable compared with secondary beliefs over time. The latter finding may suggest that some policy actors' beliefs (in this case, industry versus environmental groups) are more malleable than other policy actors' beliefs, which has yet to be examined closely in the policy process literature and could lead to a refinement in the ACF's assumptions concerning the stability of policy core beliefs.

In terms of the strategic narratives used in the documents, environmental and industry groups presented themselves as heroes, industry groups also portrayed 
themselves as victims, and environmental groups portrayed industry as a villain. Some of these characterizations changed, whereas others remained somewhat stable over time. These findings offer mixed support for our propositions that interest groups are likely to portray opposing groups as villains and themselves as victims and that these strategic frames will change over time. The propositions related to interest group strategies are based on general theoretical logic from recent work developed under the NPF, but we note that this literature is still in its infancy in developing hypotheses around the characterization strategies and how they might change over time (Jones \& McBeth, 2010). Research from other scholars that explore interest group strategy using framing in environmental policy domain (e.g., Guber \& Bosso, 2012) may offer insights to help flesh out such ideas in terms of the context within which framing strategies are employed. Given the significant role that key actors were able to play "behind the scenes" in the regulatory policy process in this case, it is possible that industry did not need to actively engage in framing its environmental opponents as villains. How the framing strategies of opposing groups in the hydraulic fracturing debate change within different policy venues and contexts are therefore another area for future research.

Interpreting beliefs and strategies and how they change over time from coded documents is a limitation of the study (e.g., Larson, 1988). As mentioned above, actors may choose to tailor narratives, framing, and other components of their communication depending on the context, audience, or timing of publication. Thus, when observing changes in actors' stated policy positions within documents and narratives over time, it may be difficult to determine whether policy actors are shifting their beliefs or if they are strategically adapting their stated positions during different stages of the process to gather support and sympathy for their preferred policy solution. At the same time, while the literature recognizes that strategies represent the attempts of actors to achieve their goals, or policy beliefs, the strategies of interest groups can also influence the secondary beliefs of actors in an interest group or coalition (Sabatier, 1998). In other words, the distinction between strategies and secondary beliefs may be hard to discern through documents produced by policy actors. Further research is needed to examine whether the documents produced by policy actors, and narrative representations within those documents, serve as a valid data source for capturing the beliefs of policy actors, as well as how beliefs and strategies interact.

Our findings from the interest group interviews offer support for many of the propositions related to the factors that precipitate policy change. The strongest support was for the timing of the policy change, a policy entrepreneur, and a negotiated agreement. At the time of the disclosure rulemaking debates in Colorado, public concern was high locally and nationally, political support and motivation was present, and industry and environmental groups supported a possible solution. Multiple interviewees describe Governor Hickenlooper as calling for disclosure and moving the process forward. Interviewees also described closed-door negotiations as key to the details in the final rule. This may be because limiting the scope of the actors who have the authority to make decisions during negotiations increases the likelihood of a successful conflict resolution (Pruitt \& Kim, 2004). Interviewees also saw learning among the industry as a factor precipitating change. During the debate, industry learned that it needed to change its policy positions to 
address public trust by providing information concerning its processes. Other states' disclosure policies were cited as important in precipitating the political debate in Colorado, although not for specific solutions used in the rule, suggesting that diffusion played a moderate role in this process. Evidence for major events was mixed. Interview respondents did not identify a single triggering event; however, two interviewees mentioned that the gradual process of encroaching oil and gas activities in urban areas was important. Collectively, these findings may suggest that the intersection of multiple mechanisms of policy change may be necessary on a highly politically divisive policy issue, particularly where major events are lacking. Moreover, the findings may suggest that particular mechanisms, such as negotiated agreements and learning, may be important pathways to policy change on a highly divisive issue such as hydraulic fracturing.

The findings from both the coding of direct communication documents by interest groups and the interviews with members of these interest groups complement each other. Utilizing two different data collection and analysis techniques allows us to develop both a broad and deep understanding of a single case of policy change. The intersection between these two forms of data collection and analysis is most clearly established when examining learning and the negotiated agreement. On the issue of learning, both the coded documents and the interviews indicate that the industry went through a learning process concerning the disclosure rule. When examining the evidence from the coded documents on the changes in secondary beliefs, we found that industry increased support for disclosure over time. This finding is complemented by our interviews, which indicate that industry learned that in order to bring about better public trust, it needed to support disclosure. On the issue of the negotiated agreement, the coded documents inform the interviews by showing how the industry and environmental groups had very different strategies during the time period of negotiation. We found that industry did not identify environmental groups as villains, whereas the vast majority of environmental group documents identified industry as the villain. This may be explained by the interviews, which indicated that the closed-door negotiations between the COGCC, Halliburton, and the EDF were supported by the peripheral industry groups, but not by the excluded environmental organizations.

\section{Conclusion}

The findings from this study offer both methodological and theoretical contributions to the policy process literature. Methodologically, the in-depth case study approach shows a meaningful way to draw out evidence on how and why a policy change occurs that cannot be found through large-n variance research designs. The interviews provided insights that were unattainable or unnoticeable from the document analysis and that would be difficult to ascertain from a large-n approach. Second, the research shows that analysis of policy actors' publications can be used to identify groups based on policy core beliefs and may, thus, provide scholars using the ACF with an additional tool for identifying coalitions.

Theoretically, the analyses help us understand the ways in which policy actors and interest groups engage one another and strategize during a period of policy change. As would be expected by the ACF, actors within interest groups diverge 
more on secondary beliefs than on policy core beliefs, yet these beliefs do not necessarily remain stable over time as expected. This may be a result of the use of policy actor "narratives" or documents as a data source for beliefs and the challenge of disentangling beliefs from strategies within these documents. At the same time, we found that the strategies employed, in terms of how actors present themselves and their opponents, offer mixed support for the NPF by showing weak support for the expected characterizations between opposing interest groups, as environmental groups portrayed the oil and gas industry as villains, but the opposite was not found. However, the expectations from the NPF may benefit from drawing insights from a broader body of literature on interest group framing to help tease out the nuances of the findings. Finally, the findings support two of the ACF's explanations for policy change, including learning and negotiated agreements, and demonstrate the value of drawing insights from a diverse range of policy change theories to uncover other mechanisms of policy change within the context of a highly divisive policy. Thus, analyzing this case study through the lens of multiple theories enhanced the understanding of the possible causal processes that could not have been achieved by using just the ACF, and offered areas for future exploration in larger-n or comparative research on hydraulic fracturing policies. Yet we would caution scholars to be sensitive to the policy context and to consider whether a single theory or comparison of multiple or alternative theories is appropriate for the issue at hand.

Our findings can also inform the emerging body of literature that has examined the politics and policies related to hydraulic fracturing. The importance of having a negotiated agreement as part of the policy change process may offer additional support for other scholars who have found that policy processes on hydraulic fracturing tend to exclude environmental and local interests (Rabe \& Borick, 2013; Warner \& Shapiro, 2013). Although the formal regulator process in Colorado was open to a diverse set of stakeholders (including a number of environmental groups), the final policy was agreed upon within the negotiated process. Given that Colorado's disclosure policy has been identified as relatively stringent and robust (Murrill \& Vann, 2012), this study offers insights that may complement recent work by Fisk (2013), who found that a number of hypothesized state-level contextual factors, such as the presence of active interest groups opposing hydraulic fracturing or liberal ideologies, do not explain the likelihood of states adopting more stringent disclosure regulations. Although Fisk found that some contextual factors such as sociodemographic status may be important, our findings suggest that factors that are more internal to the policy process, such as learning by industry, an active policy entrepreneur, or negotiated agreements, may be more important in understanding how and why a particular policy emerges.

The question remains as to whether our findings on these mechanisms of change, as well as the beliefs of interest groups and their strategies, can be generalized to other states that have witnessed policy change related to hydraulic fracturing, especially those with less stringent outcomes, such as Pennsylvania (Rabe \& Borick, 2013) and Texas (Davis, 2012). That said, given that the goal of this paper is to draw out factors that help explain how and why a particular policy change emerged, rather than assess the ability of the state to pass a particular type of rule, we would argue that theory and methods should be applicable beyond Colorado. 
Additionally, we recognize that more research would be needed to uncover how and why Colorado's type of policy outcomes would differ from those of other states and what allows particular interests to maintain their positions and interests in policy outcomes. Future research could also examine whether and how the Colorado disclosure rule of 2011 has influenced the adoption of disclosure rules by other states. Overall, the issue of hydraulic fracturing presents a fruitful area of research on policy processes and policy change.

\section{Notes}

1 For a detailed description of the ACF's belief system, see Sabatier and Jenkins-Smith (1993) and Weible and Nohrstedt (2012).

2 The complexity and ambiguity of the concept of policy change justifies the use of multiple theories when seeking valid explanation (Howlett \& Cashore, 2009). In addition, the use of multiple theories furthers our understanding of the strengths and limitations of such theories when used in concert (Cairney, 2012).

3 Technically, the ACF offers four pathways to policy change including internal and external subsystem events, negotiated agreements, and learning (Weible et al., 2011). The interview questions in this paper asked whether any major events had a role in explaining policy change (internal and external subsystem events). As will be shown, major events were not a significant factor in this particular case study. If major events were a major factor and if there were a difference between internal and external shocks as reported by the interviewees, we would have made such a distinction in the theoretical expectations. For convenience, we simply combined them in the description of the text. Like any application of the ACF, this testing is incomplete in other ways. Ideally, we would have explored the patterns of coalition behavior of extended periods of time to better understand the politics associated with the policy change as recently done by Leifeld (2013).

4 Moreover, the ACF as a "framework" used to organize this study is compatible with other theories and can incorporate them as rival or complementary explanations (Elgin \& Weible, 2013; Weible et al., 2011; Weible \& Nohrstedt, 2012).

5 The point of Kingdon (1984) was not to explain policy change but rather agenda setting and the specification of alternatives. Travis and Zahariadis (2002) extended the argument to policy change, an argument we conveniently accept to assess whether timing was an important factor in explaining this period of policy change.

6 The other documents were from local governments $(n=14)$, state government or agencies $(n=2)$, Representative Diana DeGette $(\mathrm{D}-\mathrm{CO})(\mathrm{n}=11)$, and federal agencies $(\mathrm{n}=3)$.

7 Other codes, such as the use of science and whether the framing of the document is thematic or episodic, are included in the codebook but are not used in this analysis.

8 Cohen's Kappa was not used to test the reliability of character framing codes because multiple actors could be identified for each actor type, which made it impossible to collapse the entries into a single column. Instead, iterative checking by the researchers was used to validate actor type codes.

9 Lombard, Snyder-Duch, and Bracken (2002) prescribe at least 10 percent of documents be coded by another for determining intercoder reliability when using a randomized sample.

10 According to Fleiss (1971), a Cohen's Kappa measurement of agreement at or above 0.40 is "fair" to "good."

\section{About the Authors}

Tanya Heikkila is an Associate Professor and Director of the PhD program at the School of Public Affairs, University of Colorado Denver, Denver, Colorado, USA.

Jonathan J. Pierce is a Post-Doctoral Research Fellow at the School of Public Affairs, University of Colorado Denver, Denver, Colorado, USA.

Samuel Gallaher is a Doctoral Student at the School of Public Affairs, University of Colorado Denver, Denver, Colorado, USA. 
Jennifer Kagan is Director of the Wirth Chair in Sustainable Development at the School of Public Affairs, University of Colorado Denver, Denver, Colorado, USA.

Deserai A. Crow is an Assistant Professor in the Center for Science and Technology Policy Research, University of Colorado at Boulder, Boulder, Colorado, USA.

Christopher M. Weible is an Associate Professor at the School of Public Affairs, University of Colorado Denver, Denver, Colorado, USA.

\section{References}

Baumgartner, F. R., \& Jones, B. D. (1993). Agendas and instability in American politics. Chicago, IL: University of Chicago Press.

Berger, A. A. (1997). Narratives in popular culture, media, and everyday life. Thousand Oaks, CA: Sage Publications. Berry, F. S., \& Berry, W. D. (1990). State lottery adoptions as policy innovations: An event history analysis. American Political Science Review, 84, 395-415.

Birkland, T. A. (1997). After disaster: Agenda setting, public policy, and focusing events. Washington, DC: Georgetown University Press.

Blomquist, W. (2007). The policy process and large-N comparative studies. In P. Sabatier (Ed.), Theories of the policy process (pp. 161-293). Boulder, CO: Westview Press.

Cairney, P. (2012). Complexity theory in political science and public policy. Political Studies Review, 10, $346-358$.

Cohen, J. (1960). A coefficient of agreement for nominal scale. Education and Psychological Measurement, 20, $37-46$.

Converse, P. (1964). The nature of belief systems in mass publics. In D. Apter (Ed.), Ideology and discontent (pp. 206-261). New York: Free Press.

Cormier, J., \& Tindall, D. B. (2005). Wood frames: Framing the forests in British Columbia. Sociological Focus, $38,1-24$.

Davis, C. (2012). The politics of "fracking": Regulating natural gas drilling practices in Colorado and Texas. Review of Policy Research, 29, 177-191.

Donnelly, P., \& Hogan, J. (2012). Understanding policy change using a critical junctures theory in comparative context: The case of Ireland and Sweden. Policy Studies Journal, 40, 324-350.

Easton, D. (1954). The political system: An inquiry into the state of political science. New York: Alfred A. Knopf.

Elgin, D., \& Weible, C. M. (2013). Stakeholder analysis of Colorado climate and energy issues using policy analytical capacity and the advocacy coalition framework. Review of Policy Research, 30, 116-134.

Emerson, K., Nabatchi, T., \& Balogh, S. (2012). An integrative framework for collaborative governance. Journal of Public Administration Research and Theory, 22, 1-29.

Entrekin, S., Evans-White, M., Johnson, B., \& Hagenbuch, E. (2011). Rapid expansion of natural gas development poses a threat to surface waters. Frontiers in Ecology of the Environment, 9, 503-505.

Fisk, J. M. (2013). The right to know? State politics of fracking disclosure. Review of Policy Research, 30 , $345-365$.

Fleiss, J. L. (1971). Measuring nominal scale agreement among many raters. Psychological Bulletin, 76, $378-382$.

George, A. L. (1969). The "operational code": A neglected approach to the study of political leaders and decision-making. International Studies Quarterly, 13, 190-222.

George, A. L., \& Bennett, A. (2005). Case studies and theory development in the social sciences. Cambridge, MA: MIT Press.

Gerlak, A., \& Heikkila, T. (2011). Building a theory of learning in collaborative institutions: Evidence from the Everglades Restoration Program. Journal of Public Administration Research and Theory, 21, 619-644.

Gerring, J. (2007). Case study research: Principles and practice. New York: Cambridge University Press.

Guber, D. L., \& Bosso, C. I. (2012). Issue framing, agenda setting, and environmental discourse. In S. Kamieniecki \& M. Kraft, The Oxford Handbook of U.S. Environmental Policy (pp. 437-460). Oxford: Oxford University Press.

Heclo, H. (1974). Social policy in Britain and Sweden. New Haven, CT: Yale University Press.

Heikkila, T. H., \& Gerlak, A. K. (2013). Building a conceptual approach to collective learning: Lessons for public policy scholars. Policy Studies Journal, 41, 484-512.

Hofferbert, R. I. (1974). The study of public policy. Indianapolis, IN: Bobbs-Merrill.

Howlett, M., \& Cashore, B. (2009). The dependent variable problem in the study of policy change: Understanding policy change as a methodological problem. Journal of Comparative Policy Analysis, 11, 33-46.

Hurwitz, J., \& Peffley, M. (1987). How are foreign policy attitudes structured? A hierarchical model. American Political Science Review, 81, 1099-1120. 
Jackson, R. B., Rainey Pearson, B., Osborn, S. G., Warner, N. R., \& Vengosh, A. (2011). Research and policy recommendations for hydraulic fracturing and shale-gas extraction. Center on Global Change, Duke University, Durham, NC. Retrieved from http://www.nicholas.duke.edu

Jaffe, M. (2011a, August 3). Colorado plans disclosure rule for fracking fluids by end of year. The Denver Post. Retrieved from http://www.denverpost.com

Jaffe, M. (2011b, November 1). Colorado fracking audit advises rule-tightening. The Denver Post. Retrieved from http://www.denverpost.com

Jaffe, M. (2011c, December 14). Colorado approval of fracking fluids' full disclosure came after long negotiations and nudge from governor. The Denver Post. Retrieved from http://www.denverpost.com

John, P. (2003). Is there life after policy streams, advocacy coalitions, and punctuations: Using evolutionary theory to explain policy change? Policy Studies Journal, 31, 481-498.

Jones, B. D., \& Baumgartner, F. R. (2005). The politics of attention. Chicago, IL: University of Chicago Press.

Jones, M. D., \& McBeth, M. K. (2010). A narrative policy framework: Clear enough to be wrong? Policy Studies Journal, 38, 329-353.

Kingdon, J. (1984). Agendas, alternatives, and public policies. New York: Addison Wesley Longman, Inc.

Kingdon, J. (1995). Agendas, alternatives, and public policies, 2nd ed. New York: Addison Wesley Longman, Inc.

Larson, D. W. (1988). Problems of content analysis in foreign policy research: Notes from the study of the origins of Cold War belief systems. International Studies Quarterly, 32, 241-255.

Leach, W. D., \& Sabatier, P. (2005). To trust an adversary: Integrating rational and psychological models of collaborative policymaking. American Political Science Review, 99, 491-503.

Leach, W. D., Weible, C. M., Vince, S. R., Siddiki, S. N., \& Calanni, J. C. (2013). Fostering learning through collaboration: Knowledge acquisition and belief change in marine aquaculture partnerships. Journal of Public Administration Research and Theory, doi:10.1093/jopart/mut011.

Leifeld, P. (2013). Reconceptualizing major policy changes in the advocacy coalition framework: A discourse network analysis of German pension politics. Policy Studies Journal, 41, 169-198.

Levin, D. (2005). Framing peace policies: The competition for resonant themes. Political Communication, 22, $83-108$.

Lombard, M., Snyder-Duch, J., \& Bracken, C. C. (2002). Content analysis in mass communication: Assessment and reporting of intercoder reliability. Human Communication Research, 28, 587-604.

Lustgarten, A. (2009, November 9). Natural gas drilling produces radioactive wastewater. Scientific American. Retrieved from http://www.scientificamerican.com

May, P. J. (1992). Policy learning and failure. Journal of Public Policy, 12, 331-354.

Maykuth, A. (2011, August 30). Fracking's thirst for water: A delicate dance between gas industry and river commission. Philadelphia Inquirer. Retrieved from http://www.post-gazette.com/stories/local/marcellusshale/ frackings-thirst-for-water-a-delicate-dance-between-gas-industry-and-river-commission-312485

McBeth, M. K., Shanahan, E. A., Hathaway, P. L., Tigert, L. E., \& Sampson, L. J. (2010). Buffalo tales: Interest group policy stories in greater Yellowstone. Policy Sciences, 43, 391-410.

Mintrom, M., \& Norman, P. (2009). Policy entrepreneurship and policy change. Policy Studies Journal, 37 , $649-667$.

Mintrom, M., \& Vergari, S. (1996). Advocacy coalitions, policy entrepreneurs, and policy change. Policy Studies Journal, 24(3), 420-434.

Mooney, C. (2011). The truth about fracking. Scientific American, 305(5), 80-85. Retrieved from http:// www.scientificamerican.com

Murrill, B. J., \& Vann, A. (2012, June 19). Hydraulic fracturing: Chemical disclosure requirements. Congressional Research Service. Retrieved from http://www.fas.org/sgp/crs/misc/R42461.pdf

Nohrstedt, D., \& Weible, C. M. (2010). The logic of policy change after crisis: Proximity and subsystem interaction. Risk, Hazards छ Crisis in Public Policy, 1(2), 1-32.

O'Leary, R., \& Bingham, L. B. (Eds.). (2003). The promise and performance of environmental conflict resolution. Washington, DC: Resources for the Future.

Obama, B. (2012, January 24). Remarks by the President in the State of the Union Address. United States Capitol, Washington, D.C. Retrieved from http://www.whitehouse.gov/the-press-office/2012/01/24/remarkspresident-state-union-address

Ostrom, E. (2005). Understanding institutional diversity. Princeton, NJ: Princeton University Press.

Pruitt, D. G., \& Kim, S. H. (2004). Social conflict: Escalation, stalemate, and settlement. New York: McGraw-Hill.

Rabe, B. G., \& Borick, C. (2013). Conventional politics for unconventional drilling? Lessons from Pennsylvania's early move into fracking policy development. Review of Policy Research, 30, 321-340.

Richardson, J. (2000). Government, interest groups and policy change. Political Studies, 48, 1006-1025.

Rogers, E. M. (1962). Diffusion of innovations. Glencoe, IL: Free Press.

Rokeach, M. (1973). The nature of human values. New York: Free Press.

Rose, R. (1991). What is lesson-drawing? Journal of Public Policy, 11, 3-30. 
Sabatier, P. (1987). Knowledge, policy-oriented learning, and policy change. Knowledge: Creation, Diffusion, and Utilization, 8, 649-692.

Sabatier, P. A. (1988). An advocacy coalition framework of policy change and the role of policy oriented learning therein. Policy Sciences, 21, 129-168.

Sabatier, P. (1998). The advocacy coalition framework: Revisions and relevance for Europe. Journal of European Public Policy, 5, 98-130.

Sabatier, P. A., \& Jenkins-Smith, H. (1993). Policy change and learning: An advocacy coalition approach. Boulder, CO: Westview Press.

Sabatier, P. A., \& Weible, C. M. (2007). The advocacy coalition: Innovations and clarifications. In P. Sabatier (Ed.), Theories of the policy process, 2nd ed. (pp. 189-220). Boulder, CO: Westview Press.

Shanahan, E. A., Jones, M. D., \& McBeth, M. K. (2011). Policy narratives and policy processes. Policy Studies Journal, 39, 535-561.

Shanahan, E. A., Jones, M. D., McBeth, M. K., \& Lane, R. R. (2013). An angel on the wind: How heroic policy narratives shape policy realities. Policy Studies Journal, 41, 453-483.

Shipan, C. R., \& Volden, C. (2008). The mechanisms of policy diffusion. American Journal of Political Science, 52, 840-857.

Staff. (2011, December 13). New fracking rules: What they're saying. Denver Business Journal. Retrieved from http://www.bizjournals.com/denver

Susskind, L., McKearnen, S., \& Thomas-Lamar, J. (1999). The consensus building handbook. Thousand Oaks, CA: Sage.

Travis, R., \& Zahariadis, Z. (2002). A multiple streams model of U.S. foreign aid policy. Policy Studies Journal, 30(4), 495-514.

U.S. Energy Information Association (U.S. EIA). (2012). Annual energy outlook 2012. Washington, DC: U.S. Department of Energy. Retrieved from http://www.eia.gov

Walker, J. L. (1969). The diffusion of innovations among the American states. American Political Science Review, 63, 880-899.

Warner, B., \& Shapiro, J. (2013). Fractured, fragmented federalism: A study in fracking regulatory policy. Publius, 43, 474-496.

Weible, C. M., Heikkila, T., deLeon, P., \& Sabatier, P. A. (2011). Understanding and influencing the policy process. Policy Sciences, 45, 1-21.

Weible, C. M., \& Nohrstedt, D. (2012). Coalitions, learning and policy change. In E. Ararat Jr., S. Fritzen, M. Howlett, M. Ramesh, \& X. Wu (Eds.), Routledge Handbook of Public Policy (pp. 125-137). London: Routledge.

Weiss, C. (1977). Research for policy's sake: The enlightenment function of social research. Policy Analysis, 3, 531-545.

Williams, D. O. (2011, September 21). Frack frenzy continues nationwide as Colorado officials eye new disclosure rule by end of year. Colorado Independent. Retrieved from http://coloradoindependent.com 